\title{
大型放射光施設とその生物科学研究 植木龍夫* への利用
}

日本原子力研究所と理化学研究所は, 科学技術庁の強力な支援の下に, 第三世代の硬 $\mathbf{X}$ 線領域の放射光を発生さ せる施設の建設を進めてきた. 英語名 “Super Photon ring-8 GeV” からとって SPring-8 と呼ばれる大型放 射光施設は, 兵庫県西部の播磨科学公園都市に設置され, 平成 9 年の秋からはその一般供用が開始される予定で ある.ここでは， SPring-8 施設の概要と生物科学分野での利用などを中心に概説しよう.

\section{放射光とは}

放射光とは，原子物理，核物理や素粒子物理な ぞの有力な研究手段である電子加速器などで，荷 電粒子が円運動する際に偏向電磁石から接線方向 に放射される電磁波（光）である（図 1). 加速器 実験の側から見ると，電子などのエネルギーが光 として浪費されることを意味するから，邪魔者で ある．放射光は 1940 年代に発見されたが，その 性質が明らかになるにつれて科学技術の研究にと って大変重要であることがわかってきた.

放射光は宇宙にもあり，星雲の磁場によって曲 げられた電子などから発生した放射光も観測され ている．荷電粒子が遅い速度で運動していると， エネルギーの低い（長波長の）光を放射するが， 光速に近い速度で運動する粒子は指向性の良い高 エネルギーのX線を大量に放射 する．放射光の主な性質は，

・輝度が高い（明るい光）

・指向性が良い（非常にシャ ープな光）

・赤外線から硬X線領域まで の連続スペクトル

・偏光特性をもつ

・パルス光である

SPring-8 Facility and Scientific Program in Biological and Medical Use * Tatzuo UEKI, 日本原子力研究所. 理化学研究所大型放射光施設計画推進共 同チーム
などである。

放射光研究は, 当初加速器施設の一部を使わせ てもらって利用が始められ（第一世代）, 次いで つくばの高エネルギー物理学研究所に設置された 放射光実験施設（フォトンファクトリー）のよう に放射光専用施設（第二世代）が建設された。こ の放射光を利用すると, 物質や生命の世界を詳し く調べることが可能となり, 高速度で進行する化 学反応や生物の機能などを時々刻々と観察でき る. また，高エネルギーの放射光を使らと，原子 や分子といった微細構造をはっきりと捉えること も可能となる（図 2 の光の波長と物質の大きさと の対比を参照のこと).

建設の進む大型放射光施設 (SPring-8) は第三 世代の放射光施設と呼ばれ，以下のよらな特徵を もっている.

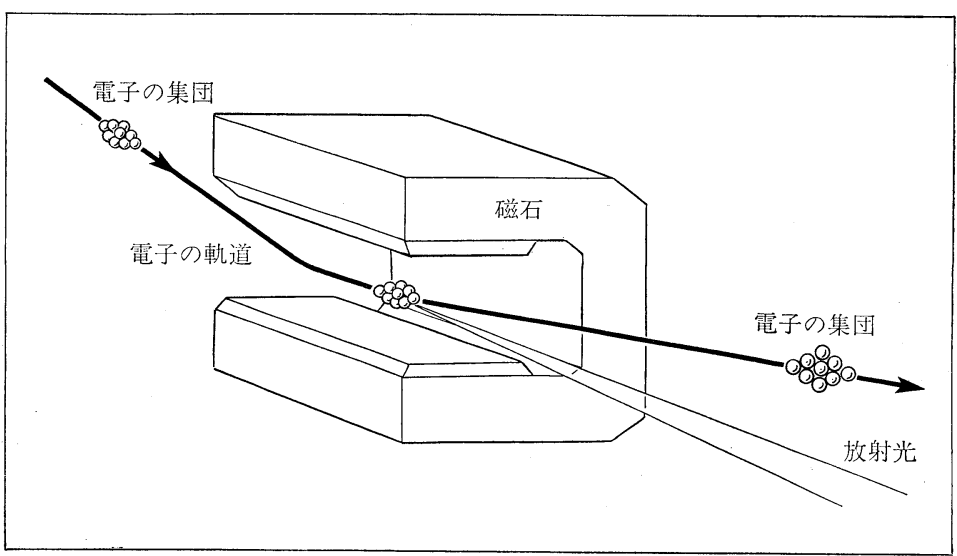

図 1 放射光発生の原理

光速近くまで加速された非常に高いエネルギーをもった電子や陽電子の軌道を電磁石 によって曲げると，接線方向に放射光が発生する. 


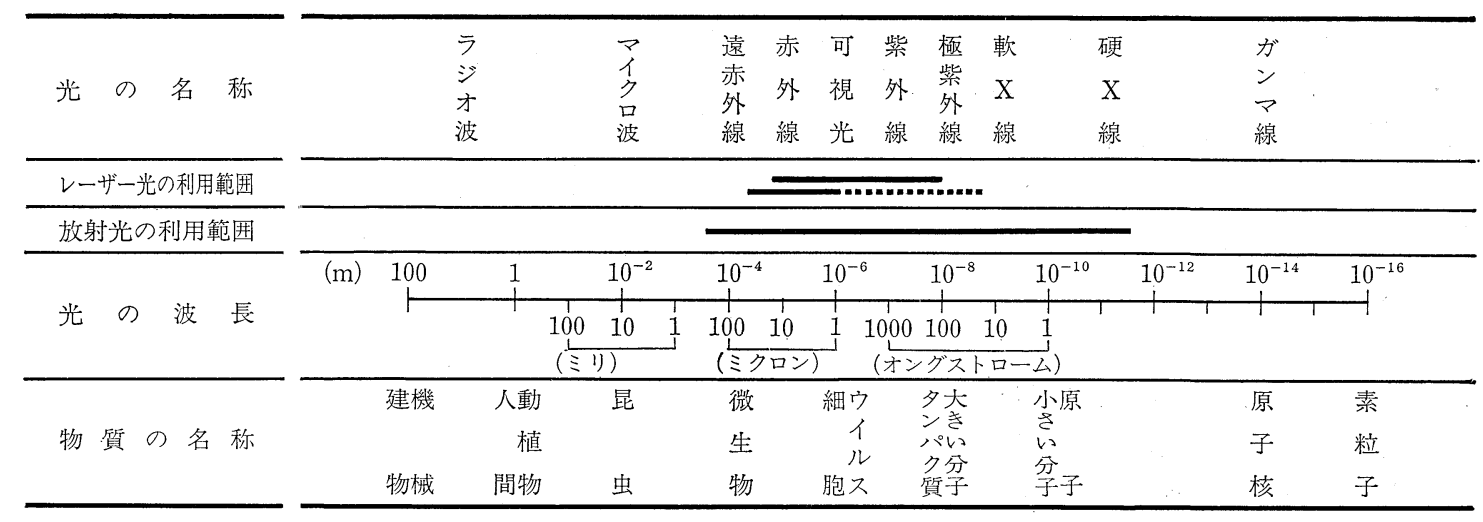

図 2 光の名称，その波長範囲と対応する物質

放射光の光 (電磁波) スペクトルのエネルギーが広域であることに注目されたい.

\section{大型放射光施設（SPring-8）}

硬 $\mathrm{X}$ 線光源の第三世代放射光 施設は挿入光源*を主体とする 施設であり，日本をはじめ，ヨ 一ロッパおよびアメリカにおい て建設されている. ヨーロッパ 放射光施設 (ESRF，グルノー ブル(仏)) ではすでにかなり の数のビームライン建設も終了 し，利用研究に使用され始め ている。アメリカ計画は APS （アルゴンヌ）と呼ばれ，1995 年春には初ビームが見られた。 日本の計画は原研・理研大型放 射光施設計画 (SPring-8, 播 磨）で，蓄積リングのエネルギ 一は $8 \mathrm{GeV}$ (80 億電子ボルト) と最屯高いが，供用開始は 1997 年になる.

大型放射光施設計画は，1986 年に理研で始められたエネルギ 一が $6 \mathrm{GeV}$ (60 億電子ボルト)

\footnotetext{
* 挿入光源：電子を円運動させるため の偏向電磁石から放射光は発生する. 軌 道の直線部に, 多数の磁極で構成される 永久磁石群や超伝導電磁石群からなる装 置を設置すると，電子が蛇行運動してよ り高輝度，高エネルギーの放射光が発生 する. この装置を挿入光源と呼ぶ.
}

(a)

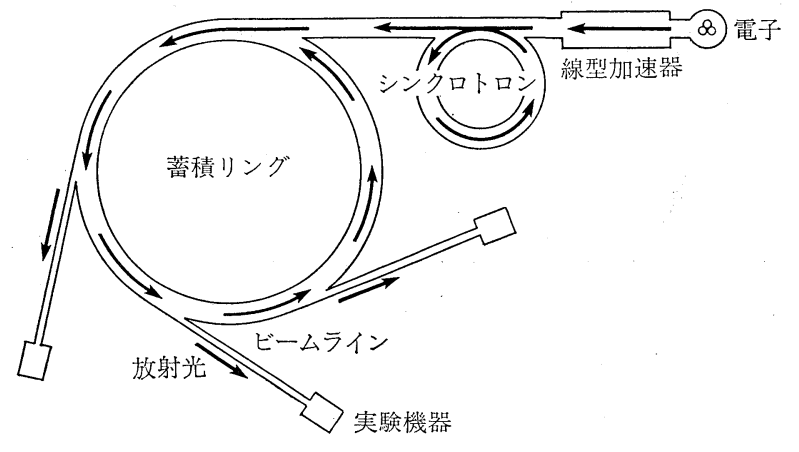

(b)

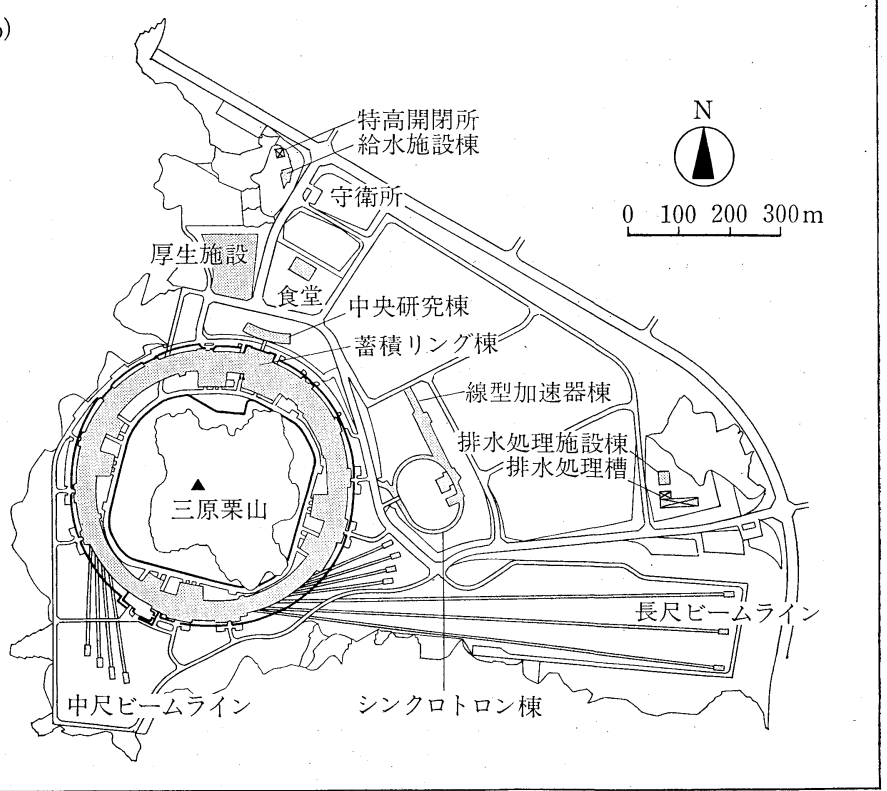

図 3-大型放射光施設の概要 (a) と実際の施設の全容 (b)

施設は入射器として線型加速器とシンクロトロンをもち，80 億電子ボルトの電子/陽電 子を蓄積リングに供給する.（b）図の蓄積リングからの中尺扔よび長尺ビームライン の配置が見て取れよ5. 長尺ビームライン（長さ $1 \mathrm{~km}$ ）から施設の大きさがわかる. 
の蓄積 リング設計研究にさかのぼることができ る. 1991 年からは, 原研 - 理研大型放射光施設 計画推進共同チームの下で建物の建設が開始され た. 加速器は, 線型加速器とブースターシンクロ トロンからなる入射器と蓄積リングとから構成さ れる (図 3).

光を発生する蓄積リングは, 電子/陽電子を加 速するための周長 $1,436 \mathrm{~m}$ のビームトンネルと 利用研究を行なう実験ホールおよび実験準備室な どをあつ. その設計パラメーターは，

$\begin{array}{ll}\text { 電子/陽電子ェネルギー } & 8 \mathrm{GeV} \\ \text { ビーム電流 } & 100 \mathrm{~mA} \\ \text { エミッタンス*1 } & 5.6 \mathrm{~nm} \cdot \mathrm{rad}\end{array}$

などで代表される．エネルギーの高さは挿入光源 からかなり高いエネルギーの光が（アンジュレー ター*2の基本波で $20 \mathrm{keV}$ 以上）放射されること が可能であることを示し，エミッタンスの小さな 值は鋭い光の放射（高い輝度）が得られることを 意味している．このように，第三世代の硬 X線放 射光施設は挿大光源, 特にアンジュレーターが主 体の施設である. $8 \mathrm{GeV}$ の蓄積リングの偏向電磁 石から放射されるビームの角度広がり*3 よそ $60 \mu \mathrm{rad}$ であるが，アンジュレーターからの 光は $20 \mu \mathrm{rad}$ 以下とはるかに鋭い. な拈, 平行光 線として喧伝されているへリウムネオン・ガスレ 一ザーの発散角は $1 \mathrm{mrad}$ ああり, アンジュレー タ一光の発散角の小ささをご理解いただけよう.

さらに，電子/陽電子ビームの大ささ（断面積） は，第二世代のマシンに比べるとずっと小さい. この光源から放射される光は, アンジュレーター の場合, 輝度として表現すると $10^{19}$ 光量子/秒に あ達する，そのスペクトルを図４に示して和こう （な拉，輝度の定義は 単位光源面積および 単位発 散立体角で規格化されたあので，実験ステーショ ンで得られる光量子数とのあのではないことを注

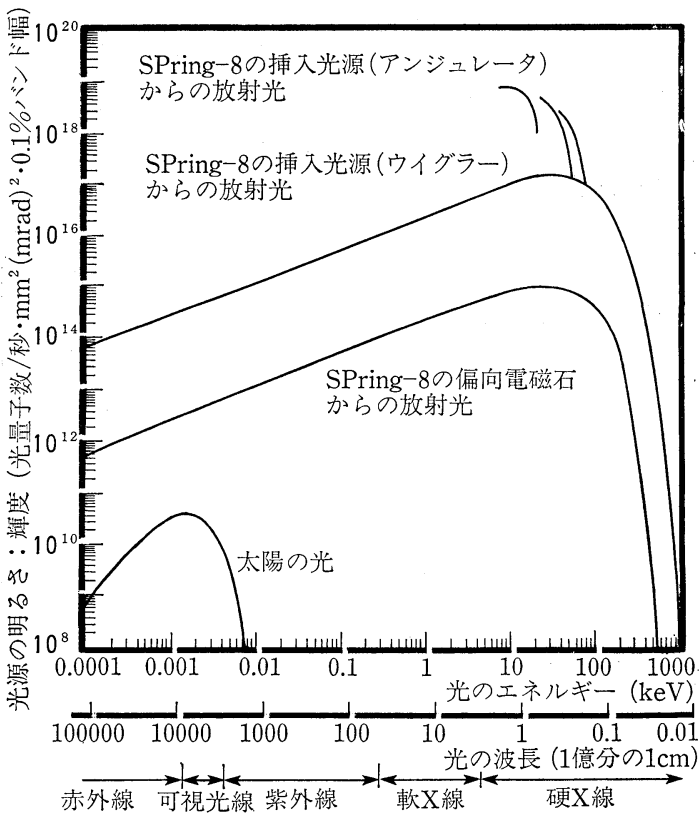

図:4 -大型放射光施設から放射される電磁波のエネルギ 一と明るさ (輝度)

最近の新しい設計ではアンジニレーター光の輝度は $10^{19}$ を越 えている. 偏向電磁石からの光も強力であるが, ウイグラー光 は高エネルギー領域でずっと明るい。

意しておく．輝度の数字ほどでもないが，第三世 代の放射光光源は，第二世代の光源に比べると 2 桁くらい多くの全線束光量子数（全フラックス） が得られる). 太陽光と比較して，そのエネルギ 一領域に格段の差があり，ずっと明るい光源であ ることがわかる。

\section{SPring-8 にどのようなビームラインが設置され} るか

大型放射光施設には 61 本のビームラインが建 設される．光源の種類別に表わすと，38 個所に 挿入光源を設置する予定である. そのうち 34 個 所には $4.5 \mathrm{~m}$ の標準長の挿入光源が置かれ，4 個所にはずっと長い挿入光源が設置でさるように なっている，また，偏向電磁石を光源とするビー

*1 エミッタンス： 電子ビームの断面積と放射される光の角度の広がりの積で与えられる. エミッタンスはリングの構造やビームの 振動的な運動に依存した量であるが，この量が小さいことは光の輝度が高いことに対応する.

*2 アンジュレーター：多数の永久磁石を規則正しく配列させた磁気回路の中を電子ビームが通過すると, 電子の軌道は何回も蛇行 させられてその都度放射光を発生する. これらの放射光は重なり合って非常に強く干涉する. その結果, 特定のエネルギーの光が高い 輝度で得られる. このような放射光を得るための装置をアンジュレーターといい, 第三世代放射光施設では主要な光源となる.

*3 角度広がり：電子が光速に近い速度で運動していると, 放射光は非常に狭い角度範囲に放射される. この值は, 電子のエネルギ 一の逆数に比例する. 
ムラインが 23 個所に建設され る予定である。

挿入光源は, 主としてその輝 度の高さを生かしたアンジュレ ーターが設置される予定である が，高エネルギーおよびその連 続スペクトル性を生かした実験 を行ならためにウイグラーも建 設され，めわせて先端的・挑戦 的な研究が推進されよう.

偏向電磁石光源は, 挿入光源注どの際だった特 徵をあっているわけではないが，連続スペクトル 性と高強度（高フラックス）を生かして，どちら かといらと沉用測定装置と組み合わせて用いられ ることが多いと考えられる.

蓄積リング棟内の実験ホールでは, 外壁沿いの 通路までに打拈よそ $80 \mathrm{~m}$ のビームラインを設置 することが可能である. 61 本のビームラインの らち 49 本はこの “標準長” のものとなる. 蓄積 リング棟には，さらに，300 m の “中尺”のビー ムライン 9 本执よび 3 本の $1,000 \mathrm{~m}$ の “長尺” ビームラインを設置できるように蓄積リングおよ び地形が整えられている(図 3-b). これらのビ ームラインの利用の内訳は,

共同利用ビームライン

30 本以上

特定利用ビームライン（大学, 研究所, 企業な ぞで建設費を自ら調達し, 自前で建設, “専有”

\section{して利用する)} 10 20 本程度

施設者用ビームライン 未定

となっている.

共同利用ビームライン（共用施設）とは，施設 内外の研究者の建設提案を受けて原研 - 理研の責 任で設計・製作するあのである，完成後には，国 内外の研究者に広く開放され, 研究課題申請に基 づいて利用が行なわれる. 利用のスタイルは,つ くばのフォトンファクトリーの共同利用を想定す るとよい. 平成 9 年度中には 10 本の共同利用ビ ームラインが建設され，共同利用に供されること

* (財)高輝度光科学研究センター : 大型放射光施設を核とし て産・官・学の緊密な連携の下に, 高輝度放射光に関する研究 開発を行ならとともに，それを管理運営し，国内外の研究者の 共同利用に供する役割をもった機関.
となっている(表 1 参照).

一方，特定利用ビームライン（専用施設）は， 大学, 研究所, 地方自治体や企業など特定の機関 からの建設・設置希望計画に対して, (財)高輝度 光科学研究センター*での審査を経て, 提案した 機関の費用負担に基づいて建設・利用されるもの である.ただし, 挿入光源の建設については加速 器への影響を考慮し, センターと協議, 協力して 建設することとなって扔り，また基幹チャンネル などの建設に関しては共同利用ビームラインに設 けた標準規格などに従い, センターの指導・協力 の下で建設される. 建設終了後, 提案者が一定期 間，専有して利用することとなる.

その他, 原研执よび理研はその研究所固有の研 究を推進するためにビームラインを建設すること となっている，また，建設主体である共同チーム がビーム診断や研究開発などの目的のために使用 するビームラインの建設あなされよう.

\section{SPring-8 を使って何を研究するか}

光など電磁波は, 身の回りの理科学機器を見て あわかるように，実験手法の中心に位置している ことは言らまであない.それは，光が計測用のプ ローブとして大変簡便であることああるが，電磁 波と物質の相互作用が多岐にわたっていることが 大きな理由である. 電磁波と物質の相互作用は基 本的には散乱と吸収である。散乱には，入射およ び散乱X線のエネルギーが変わらない弾性散乱と 変わる非弾性散乱がある. 前者は結晶からの回折 現象として現われ, 回折・散乱法は生体高分子の 結晶中や溶液中での構造研究の有力な手段であ る. 
電磁波の物質による吸収効果は多くの研究手段 に結びついている，光電吸収は物質の電子状態， 表面の物性, 化学分析や構造研究などの研究に使 われる，たと觉ば，金属原子を含む蛋白質分子 の場合，金属原子の X線吸収端の前後の吸収ス ペクトルは XAFS (X-Ray Absorption Fine Structure）と呼ばれ，金属原子周辺の他の原子 の配置に関する知見を与兄る。物質による吸収 は，レントゲンによるX線の発見の直後から医学 診断に応用されたことであ有名である。さらに， 電磁波の吸収は分子，細胞などに損傷を与える が, 光化学反応の分野では有力な方法である.

以下に，放射光の主に生物に関連した研究につ いて簡単にふれよう。

\section{原子・分子レベルの構造研究}

\section{結晶構造解析}

ラウエによる結晶からのX線の回折現象発見以 来, X線回折法は結晶中の原子の配列一三三次元 立体構造一一解析のための最む有力な手段であ る. 核酸の二重らせん構造の解析，ミオグロビン やへモグロビンの結晶構造研究などで最初に実を 結んだ生体高分子の原子レベルでの立体構造研究 は，40 年たった今であ有力な手法であり，「プロ テインデータバンク」には現在 3,000 を越える構 造情報が登録されている。

X線を使った結晶構造解析の原理は, 光学顕微 鏡や電子顕微鏡の原理にそって説明される。通
常, 光学顕微鏡による結像の原理は幾何光学によ って直観的に理解されているが，その空間分解能 などを厳密に議論しようとすると, 波動光学的な 背景が必要とされる。図 5 に示すように, レンズ による結像は 2 枚のレンズによる 2 段階のプロセ スに分けて考壳られる。やや専門的になってしま らけれども, 波動光学的に表現すると, レンズ 1 の焦点面（回折像の位置）には照射された光の対 象物体による散乱が, 数学的な言葉でいうと“フ ーリエ変換”量として与兄られる。 これは物体か。 ら散乱された光波の振幅である。もしも，この焦 点面にフィルムを置くと, 散乱された光波の振幅 の自乗, つまり光の散乱強度が記録される. 光学 の結像では, レンズ 1 の焦点面での散乱光はレン ズ 2 によって再度 “フーリエ変換”されて再生像 を図のように結像することになる。

$\mathrm{X}$ 線回折法の場合, X 線を照射すると結晶を構 成する原子から散乱された X 線が干渉してブラッ グ反射を与えることは，多くの方が学生実験で経 験されているであろら。このフィルム上に記録さ れたブラッグ反射は, 図での回折 X線の強度で, その位置と強度は結晶中で原子がぞのように配置 しているかを反映している，X線では物体による 屈折率が限りなく 1 に近いのでレンズは存在しな いが，波長が非常に短いので回折強度をレンズな しに記録（フラウンホーファー回折といら）でき る. ところで, 波動物理学の初歩的な知識による と, 波の強度を記録することはその位相を失うこ とであある. 光学顕微鏡の場 合, 回折された光は記録される ことなくレンズ 2 で結像され る、X線にはレンズが存在しな いので, X線の結像は回折され た X線の振幅と位相から電子計 算機を使って行なわれる.X線 結晶構造解析の要は, 古くから “位相問題”として知られるこ の位相決定にある.

生体高分子を対象とした結晶 構造解析の問題は, 結晶化, デ 一夕収集, 位相決定, 電子密度
図 5 波動光学的な結像の概略

光学レンズによる結像は 2 段階の光学的なプロセスによって理解されている. 
の計算执よびペプチド鎖のトレースといった点で ある.このらち, 放射光の利用によって, データ 収集打よび位相決定問題に大きな進展が見られて いるこここでは，あまり専門的にならないといっ た点から, 主にデータ収集についての最近の進歩 に説明を加えよう。

通常の実験室での実験は，いわゆる“四軸型自 “動回折計”による測定から，高性能二次元回折像 記録装置である“イメージングプレート”を装備 した回折計へと移行している，その結果，たと兄 ば理化学研究所に設置されている回折計では, 24 時間以内に一組の回折強度データを記録すること は容易である，通常の構造解析には数組のデータ セットが必要であるから，測定されたデータの質 に基づく取捨選択などの点を加味すると， 1〜2 週間でデータ収集が可能となっているといえる.

加速器からの放射光の寄生的利用が始められた 当初から, 生体高分子結晶構造解析での利用は精 力的に取り組まれてきた。第三世代の放射光光源 での利用研究としてますますこの分野の重要性が 増しているようである．現在建設が進められてい る生体高分子結晶構造解析用の複数のビームライ ンでの評価では，1回の測定は 1 秒程度であり， 一組のデータセットの収集は 10 分内外となるで あろら。したがって, 数時間内での全データ収集 は，むはや実験の律速段階とはならず，他の問題
に集中できることを可能としている．あう一つの 位相決定に関する問題でも，放射光では使用する 波長を自由に選択できる特徵を生かして“多波長 異常散乱回折法” (MAD, Multiple Wavelength Anomalous Diffraction) が提案され, 解析的な位 相決定を通じての電子密度の計算がなされるよう になってきた。

表 1 に揭げた生体高分子結晶構造解析ビームラ インでは, 主に結晶構造解析を従来の解析法に従 ってルーチン化して行らことを当面の目標として いる，一方，後述の理研ビームラインでは，多波 長異常散乱回折法による自動的な構造解析をめざ す.

\section{溶液散乱法（小角散乱法）}

結晶中での構造解析は，原子レベルの立体構造 を与える. この手法での問題は，周知のごとく， 結晶化である．近年の結晶化技術の進歩は，その 困難さを減らしてはいるものの，依然として厳然 と存在している，X線小角散乱法は，水溶液中に ある生体高分子の大きさや大まかな形状などを与 える，得られる情報は結晶構造解析に比べものに ならないくらい少ないが，結晶化の必要がないの で簡便に粒子構造の概要が解析される，その原理 は，結晶構造解析と同じである，水溶液中で，酵 素反応や環境の変化に伴って分子の構造が大きく

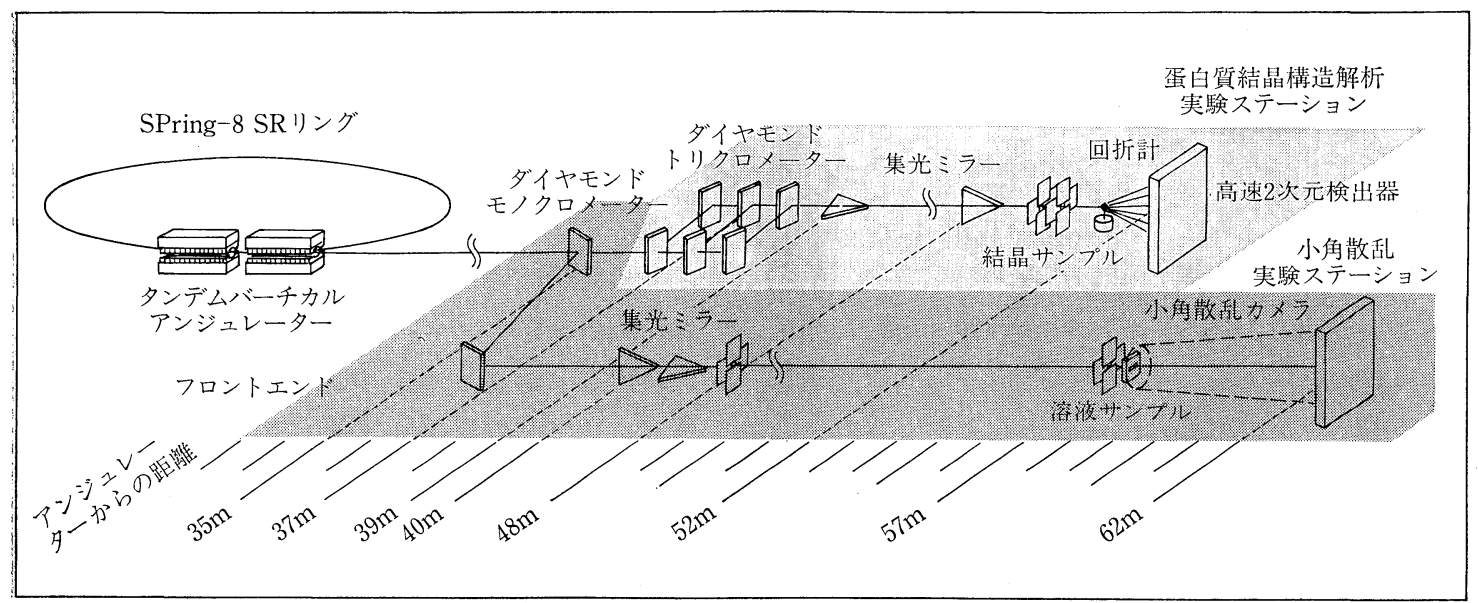

図 6・理研ビームライン（構造生物学研究）の概略

ダイヤモンド単結晶によるビーム分岐技術を使ってビームを分岐し, 蚉白質結晶構造解析実験ステーションと小角散乱実験ステーシ ョンは同時に並行して運転できるように設計されている。 
変化するような場合には大変有効な手法である. 近年，蛋白質分子の“折りたたみ”の構造面から の研究にも有効性が実証されつつある.

また，溶液散乱ではないが，小さい角度での回 折像を対象とする繊維状物質に関する研究も活発 に行なわれてきた．筋肉の収縮と並行した回折実 験は, 放射光利用の当初からの重要な研究課題で あるが，現在であ精力的に行なわれている.

図 6 には建設中の理研ビームラインの概略を示 す.このビームラインはダイヤモンド単結晶を使 ったビーム（エネルギー）分岐技術を利用しよう とするあので，1本のビームラインで複数の実験 ステーションを同時に働かせようとするあのであ る. このビームラインでは, 構造生物学的研究を 念頭に置いて，小角散乱和よび MAD 法を中心 とする結晶構造解析法を駆使して構造研究を行な らことを意図している.

\section{$\mathbf{X}$ 線微細構造吸収法 (XAFS)}

$\mathrm{X}$ 線吸収法は大変古くから知られている手法で ある．放射光の利用開始によって十分な強度をも った連続 X線源が入手できるようになったことか ら, 有効な研究手法として再登場した. 生体高分 子の場合，金属を含む分子の金属原子のX線吸収 端前後の吸収を対象とする. 吸収スペクトルの微 細構造から, 金属原子の周辺の原子の構造一一距 離, 配位数拉よびその構造一が解析される. へ 么蛋白質など金属蛋白質の金属原子周辺の局所構 造とそのリガンド結合時の構造の変化など, 有用 な研究成果が得られている.

\section{イメージング}

第三世代の放射光光源はアンジュレーターを主 体とする施設である.ビームの鋭さ（小さな発散 角）からいってあ，その優れた可干渉性を利用し た研究テーマの重要性が理解されよう.

\section{$\mathbf{X}$ 線顕微法}

生物の機能を種々の段階で研究するとき, 対象 をその機能のレベルにあわせて “観る”，つまり 構造を明らかにすることは基本的に重要である.
その構造とは, 詳細な原子レベルから始まって極 端には個体レベルまで含まれる. 光学顕微鏡で は，生きたままの生物を観ることができるが，そ の分解能からいって識別できる大きさに限界があ ることはよく知られていることである，電子顕微 鏡では十分な分解能があるが, “wet”な状態での 観察の困難さ，生体試料のコントラスト㧊よび電 子線損傷の問題がある.

ところで, 酸素原子と炭素原子のX線吸収端は 特拈よそ 2 と $4 \mathrm{~nm}$ にあって, この特性はX線を 使った生物の観察に生かすことがでさる。つま り, この領域のX線を使用すると水の吸収を避け て生物（炭素原子が主体）のコントラストを強調 できることから, “wet”な状態の生物試料を数十 $\mathrm{nm}$ といった高分解能で観察できる可能性がある といらことである，さらに，むしも干渉性の良い ビームが得られると，X線ホログラフィーといっ た三次元的な結像手法が可能となり，もっと多く の構造情報から生物の機能を理解することが可能 となろら，最近では，X線をマイクロビームに整 形する多くの技術が開発されてきた。したがっ て, 新しい結像 (イメージング) 法が生物研究に 有効な情報をむたらすこととなるのは疑いない.

\section{医学利用}

放射光の利用のかなり初期から，医学分野にお ける応用が取り上げられてきた。たと艺，近年 の心臓疾患, 冠状動脈欠陷の診断——ンジオグ ラフィー——な゙への応用である. いくつかの研 究グループが，造影剤であるヨウ素原子のX線吸 収端前後での撮像から血管の像を浮かび上がらせ る差分造影法の開発に取り組んできたが，現場で の使用屯始められているようである。また，放射 光光源は特定のエネルギーをあった $\mathrm{X}$ 線ビームを 取り出せるので, 特定の単色X線を使ったトモグ ラフィー（断層撮影）は像の質の向上をむたらす ので有効であろう。

医学利用といらと, 治療に関する問題に興味が ある、まだ具体的な成果が上がっているとはいえ ないが，ある特定の原子の X 線吸収端のビームを 照射することにより，その原子からの光電子など 
で周辺の悪性の組織を攻撃するといった方法など が提案されている.

\section{おわりに}

第二世代の 放射光施設の 利用が開始されたと き, 我々は実験室のX線発生器と比べてその強度 の利得に感動したものである. 小角散乱実験で は, 実験室の発生器とライン光学系を組み合わせ た測定器を比べると, 抒和よそ500 倍の強度の利 得をむたらした．実験データに複雑な補正を加兄 る必要がなくなり，1回の測定時間は桁違いに短 縮されたので, より希薄な濃度の水溶液を実験の 対象とすることがでさるようになった．測定時間 の短縮は, 種々の水溶液の条件に置かれた生体高 分子からの小角散乱実験による構造研究が容易と なり，その結果生物学的に重要な構造と機能の関 係など多くの成果が得られた。

蛋白質結晶の構造解析についても事情は同様で ある．短時間に質の良い，より高分解能のデータ が得られるようになった。また，実験室の $\mathrm{X}$ 線発 生器を光源としたとき, 金属原子としては低濃度 である金属蛋白質の XAFS 実験は困難であっ た.しかしながら，前述のように，放射光光源の 出現によってはじめて本格的な実験が行なわれる ようになり，へム蛋白質や光合成系のマンガン蛋 白質などの局所構造研究が進展した. このような 研究は，X線顕微鏡の開発などあ含めて, 基本的 には連続スペクトルの活用はあるものの強度の利 得を最大限に使ったものであるといえよう.

第三世代の大型放射光施設 でのビームライン 建設提案の多くは, やはり強度一全フラック ス——念頭に置いたものである．第三世代の研 究課題をここで述べるとしても，所詮は筆者の第 二世代施設の利用研究の延長上にしかないと思劣 るし，将来実現される第三世代光源を使って行な われる新しい研究課題からほど遠いかもしれない ので，ここでは新しい課題の掘り起こしにつなが るかあしれないいくつかのキーワードを挙げるに とどめる.

第三世代の光源の特徵から,

・高エネルギーX $\mathrm{X}$ 線
・ビームの干渉性

・小さいェミッタンス

・数十ピコ秒の単一バンチ

といったキーワードと結びつけられるよらな新し いサイエンスの展開が期待される. 面白い研究課 題の提案を和願いして筆を置くことにする.

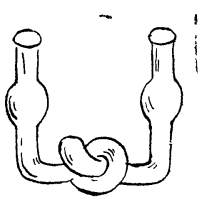

